\title{
Architecture and Gender : Lessons from Building Archaeology in Africa
}

Lorenzon, Marta

Springer

2020

Lorenzon, M 2020 , Architecture and Gender : Lessons from Building Archaeology in Africa . in J Nitschke \& M Lorenzon (eds), Postcolonialism, Heritage, and the Built Environment : New Approaches to Architecture in Archaeology . SpringerBriefs in Archaeology , Springer , Cham , pp. 13-25 . https://doi.org/10.1007/978-3-030-60858-3_2

http://hdl.handle.net/10138/339517

https://doi.org/10.1007/978-3-030-60858-3_2

acceptedVersion

Downloaded from Helda, University of Helsinki institutional repository.

This is an electronic reprint of the original article.

This reprint may differ from the original in pagination and typographic detail.

Please cite the original version. 


\title{
Chapter 2
}

\section{Architecture and Gender: Lessons from Building Archaeology in Africa.}

Marta Lorenzon

\begin{abstract}
This chapter focuses upon the role and contribution of women in the architectural process, specifically in earthen architecture, discussing numerous case studies from Africa. The main aim is to foster interdisciplinary research, combining building archaeology, ethnoarchaeology and postcolonial theories to shed lights on understudied aspects of earthen architecture. This contribution also presents the case for a more participative form of archaeology based on community engagement as a key aspect in the analysis of the architecture from archaeological contexts. The chapter addresses two major questions: what is the impact of postcolonial theories on the analysis of earthen architecture in building archaeology? How gender and subaltern studies have improved our understanding of the construction process and overcome pre-existing discipline bias?
\end{abstract}

Keywords: earthen architecture, decolonization, gender, building archaeology, African archaeology. 


\section{Introduction}

In archaeological research we tend to associate the design and creation of architecture and the built environment with men. However, there are many examples of the prominent role of women in the creation of the built environment, both in modern and ancient contexts. For example, in sub-Saharan Africa there are numerous instances of women playing a significant role in the architectural process and participating actively in the construction and decoration of architecture (Blier 1994; Dalton 2017; Jolaoso 2001; Morton 2007: 168-169; Odeyale and Adekunle 2008). Archaeologists, however, tend to overlook the role of women in the architectural processes of the past, and gender bias persists in the analysis of architectural remains. This is well exemplified by the male narrative which is dominant on the archaeological research on the topic (Prussin 1995: 58; Tringham and Chang 1991; Wylie 1991). Part of the reason for this is that while the postcolonial critique and gender theory have become a mainstay of current archaeological thought, they have only been incorporated in a limited way into the study of architectural remains in the archaeological record. As explored in the introduction to the volume, architecture is still too often treated as the setting rather than as an active agent in social life that both reflects and shapes human experience. Through the new discipline of building archaeology together with ethnoarchaeological approaches, we can begin to correct these problems and misconceptions. The case studies I am discussing in this contribution show the importance of integrating these two disciplines, building archaeology and ethnoarchaeology, to investigate the built environment through more inclusive and encompassing lenses.

\section{Gender Theory and Archaeological Approaches to Architecture}


Building archaeology, or archaeology of architecture, is a distinctive branch of archaeology that concentrates on the analysis of architectural remains - the built environment — as part of material culture (Egenter 1992; Steadman 1996). Building archaeology focuses on studying architectural remains through a combination of macroscopic and microscopic observation to investigate the multiple steps of construction, building functions, and eventual alteration to original structures as key evidence of the socio-cultural and economical information embedded in the built environment (Bartlett 1994; Butzer 1976; Rapoport 1969, 1976; Steadman 1996). Building archaeology plays a critical role in offering insights into the life of past and present communities through the artificial, human-made landscape, in which interactions take place, peoples' belief and values are tangibly represented, and a space for industriousness and creativity is created (Hodder 1994; Horton 1994).

The traditional approach to architecture in archeology has tended to problematically divide architectural remains into the fixed categories of "polite" versus "vernacular", especially within western academia. "Polite" architecture is often used to describe buildings that are the product of elite classes and are designed and built following a predetermined set of conventions. "Vernacular" architecture is often conceived as that which represents the non-elite part of society, in which architectural form is determined by local knowledge and materials arranged in a mere functional fashion (Archer 2005; Brunskill 2000: 27-31; Upton 1983). This division oversimplifies the series of entangled and multifaceted relationships communities have within themselves and with the built environment, including the relationship between architecture and power. Glassie's $(1984,2000)$ and Güvenç's (1990) research have extensively broadened the term "vernacular", arguing that the lexis should include the full range of the built environment, 
overcoming the strict taxonomic divide between vernacular and polite architecture, which was created during the "modernization of the profession" (Güvenç 1990: 286). More recently, studies on earthen architecture as a form of construction that can be included in both categories have helped to blur the "vernacular" vs “polite" divide (Blier 2006: 230-239; Herrmann 1999; Hodder 2000). Although earthen materials have traditionally been broadly considered as characteristic of vernacular architecture, recent work has brought attention to the fact that from prehistory until the present earthen material has also been employed worldwide in monumental structures, for example at sites such as Uruk, Djenne, Malia, and Merv (Bourgeois 1987; Devolder and Lorenzon 2019; Herrmann 1999; Strommenger 1980). The study of earthen architecture in what are classically defined as polite and vernacular contexts has also widened the set of interdisciplinary data archaeologists employed in their investigation and interpretation, such as records collected through geoarchaeology, building archaeology and ethnoarchaeology (Aurenche 1993; Gosden 2001; Liebman 2008; Trigger 1984; van Dommelen 2011).

\section{Gender theory in archaeology}

Gender theory in archaeology emerged from the lack of inclusion in researching gender and social roles in past societies, in which "archaeologists, consciously or not, are propagating culturally particular ideas about gender in their interpretation and reconstruction of the past" (Conkey and Spector 1984: 2). Gender theory focuses on widening the interpretative horizon to include, for instance, female, trans-, and generally non-binary perspectives and representations that have been seriously underrepresented as an active agent in the creation of material culture (Conkey and Spector 1984: 4-7: Gilchrist 1999, 2004; Sørensen 1996). Analysis of material 
culture in archaeological research has traditionally focused on elite material expressions and then extrapolated these as representing the experience and point of view of all members of society. Gender theory is one way that archaeologists have sought to include narratives that were previously excluded, in order to achieve a more comprehensive and inclusive understanding of past society (Tringham and Chang 1991; Tringham 1994; Gilchrist 1997; 1999).

In building archaeology, archaeologists have put gender theory into practice by providing an approach directly based on ethnoarchaeology to reshape and rethink gender dynamics within past societies based on a task-differentiation framework (Conkey and Spector 1984: 14-28; Spector 1983: 90-95). This framework calls for an analysis of the archaeological record based on the social, temporal, spatial and material definition of any given activity such as raw source procurement and building construction. The existing androcentric bias in archaeology has been compounded by the lack of archaeological data linked to gender roles in architecture and the tendency of Western perspectives to associate certain pursuits, such as architecture, with masculinity and thus the 'androcentric' domain. By contrast, a task-differentiation approach together with ethnoarchaeological research have progressively dismantled the foundation of this bias and created a more inclusive gender narrative for archaeology (Conkey and Spector 1984; Joyce 2000, 2004; Miller 1988; Sørensen 1996; Spector 1983; Tringham and Chang 1991; Wylie 1991). In building archaeology, ethnoarchaeology has been employed as a useful method to bridge these various gulfs as shown by numerous case studies that in the last decades helped disprove these androcentric stereotypes, demonstrating a long-lasting relationship between female craftmanship and architecture (Blier 1981; Joshi 2011; LeMoine 2003; Miller 1988; Mills 2013; Tringham 1994). Within this new theoretical framework, it is impossible to disregard the reductive narrative frequently employed in the analysis of architectural remains from 
archaeological sites regarding gender, especially when local and indigenous communities were excluded from their investigation and interpretation (Boivin 2008; Gamble and Porr 2005; Ingold 2000; Kusimba 2017). The following discussion presents case studies that employ these aforementioned approaches to discuss the architectural creation of underrepresented groups, community narratives, and their archaeological values in Sub-Saharan Africa. These case studies demonstrate the importance of integrating ethnoarchaeology in building archaeology to reach an in-depth understanding of gender dynamics in the building process.

\section{Case Studies from African Archaeology}

Several case studies from North and Sub-Saharan Africa exemplify the importance of interaction between ethnoarchaeology, building archaeology, and gender theories as described above. In a study focused on Nubian earthen architecture, Dalton (2017) employed geo-ethnoarchaeological methods to investigate the creation of mud plaster and the related specific social practices near Amara in Northern Sudan. His investigations revealed a gender role division within the earthen construction process of the region: while the men carried out the bulk of the building activities, the women were in charge of the mud-plaster preparation and application. His descriptions of the active role of female plasterers, who use specific and diverse methods of raw material procurement, and their individual plaster recipes support the idea of a specialized craftsmanship and a diachronic skill transfer among craftswomen (Dalton 2017: 357-388; Elcheikh 2018: 245). Through the collection of ethnoarchaeological and geoarchaeological data from modern domestic contexts, this work provides fresh insights into the gender roles in local building practices in Amara, especially regarding the women's contribution to house construction and maintenance 
(Dalton 2017) (Figure 2.1). The comparison of these data, specifically micromorphological data regarding seasonal plastering from historical and modern domestic contexts, highlights the presence of personalized recipes in the ethnographic and archaeological record in Amara, trailblazing the relevance of ethnoarchaeology in understanding past architectural practices, while also suggesting that we think more critically about question of women's contribution to the building process in the past (Dalton 2017: 369-381).

Similarly, in Togo, Blier's (1981) analyses of historical earthen construction have drawn attention to the role of female plasterers and decorators working alongside male architects. In this case, ethnoarchaeological evidence suggested both roles were based on a strict apprenticeship and were regarded as having a high social status within the Tamberma community (Blier 1981; Morris and Blier 2004: 201-204).

Studies of other Sub-Saharan pre-colonial architectural traditions have also highlighted the significant role of women in the creation of the built environment, presenting tangible evidence from multiple sub-Saharan communities, such as Ghana (Frafra women), Kenya (Kikuyu women), Zimbabwe and South Africa (Ndebele women) (Arceneaux 1989: 82-84; Leakey 1977: 139-143; Odeyale and Adekunle 2008; Prussin 1969: 57, 88; Sheldon 2017: 1519; Sogah 2010: 25; Whelan 2003) (Figure 2.2). Odiaua (2008) further stresses how women in Daura communities (Nigeria) not only as worked as decorators, but also took an active part in the construction process, such as overseeing flooring and roofing. While the construction of walls and foundations is a male responsibility, women take over to prepare the roof finishing and ensure waterproofing (Odiaua 2008: 121).

In the Maghreb and Saharan desert, Prussin (1995) describes extensively the role of women builders in nomadic communities through archaeological and ethnographic data. For 
example, in the cases of Toubou (Lybia-Chad), Kababish, and Mahria nomadic communities (Sudan), the pitching of the tent, its design, the selection of building materials, and structural stability are always a female responsibility (Holter 1995: 130-133; Prussin 1995: 56-58). In addition to ethnographic data, Prussin also points to rock paintings in Tassili n'Ajjer (Algeria), which portrays female figures building a tent. This seems to mirror the evidence of her ethnographic research on the presence of women builders in the nomadic Saharan communities.

These examples illustrate the importance of women in the creation of the built environment in African landscapes, in which women have been and continue to be in charge not only of the raw source collection, but also of the design and construction of flooring, roofing, and plastering in both domestic and non-domestic structures (Jolaoso 2001; Odiaua 2008; Prussin 1974; Van Vuuren 2008a and 2008b; Whelan 2003). This reality underscores the need to incorporate gender studies more systematically in building archaeology and the importance of local community knowledge in understanding the significance of material culture and architecture as social agents. First, gender studies open a new level of investigation that overcome the characterization of architecture from archaeological context as a "masculine accomplishment" prominent in Western academia (Tringham 1994; Sogah 2010: 12-13).

Second, the inclusion of local narratives helps to reverse colonial misconceptions about factors such as gender and produce a more complex, nuanced and genuine interpretation of the archaeological data. Schmidt $(1983 ; 2014)$ has been an early proponent of the importance of community inclusion in Africa, especially Tanzania, in answering archaeological questions that focus on identity and social roles. His research has played a key role in raising community engagement as an active investigative tool of ethnoarchaeological research and decolonizing archaeological practice in Africa. Schmidt (2014) also raises the important issue of how 
archaeology can impact the everyday life of local communities and the importance of oral traditions in understanding the values and significance of built environment. Community engagement with indigenous and local communities is already part of the archaeological practice in numerous Western contexts, such as in North America where Native American communities are a key stakeholder in archaeological investigations. In these cases, archaeologists often pushed by government regulations, learned to engage with local communities as equal partners (Kusimba 2017; Nicholas et al. 2008; Nicholas 2010; Pereiria Campos and Heinsen Planella, this volume). As a result, the inclusion of diverse narratives and a more public approach has improved the ways archaeological and anthropological projects are designed, executed and disseminated (Ataley 2012; Schmidt 2014; Moser et al. 2002; McKinnon et al. 2014).

In Africa, unfortunately, community-inclusive approaches such as just described are still the exception rather than the norm. Local communities who are an essential stakeholder of architectural and archaeological research are often not included, even though community collaboration is crucial for understanding not only the building process, but also the values communities embed in buildings, and the craftsperson's social role within the community (Dalton 2017; Fodde 2009; Lorenzon and Sadozai 2018; Morris and Blier 2004). The author's ethnoarchaeological and community project at the site of Tell Timai, Egypt, carried out within the University of Hawaii at Manoa excavation project, aimed at including local communities in the archeological process with a shared focus in better understanding the construction process, while increasing awareness and preservation of the archaeological site among the local community (Lorenzon and Zermani 2016). The project targeted two specific types of audience: children through a bilingual book and a series of educational initiatives, and members of the community through an earthen architectural preservation project that directly involved local 
expertise and knowledge (Lorenzon and Zermani 2016). The need for overcoming the disenfranchisement of most local communities from their local heritage is one of the biggest challenges for community engagement, as it impacts not only the everyday protection of archaeological heritage but also the preservation of skills and expertise within local communities, which belong to the intangible heritage domains (Hanna 2013; Ikram 2013).

In the course of the Timai project, local knowledge of earthen architectural practices and techniques was invaluable not only for its ability to improve our academic knowledge, but also for its role in bridging local community and experts and creating a better understanding on how the whole community, women and men, participate to some degree in the construction process. For instance, members of the Tell Timai community described in detail the process of earthen plaster production and application, which included more steps than is usually assumed by archaeologists. The builders revealed that an important step is to include incisions of the first plaster layer to guarantee more grip to the successive coatings, which we were unaware of. This is a concrete example of the importance of integrating local knowledge in archaeological projects. In this case this step was added to the earthen conservation practices in Timai and it was possible to finally explain the perpendicular incision found on historical plaster recovered at the site. The benefits of community engagement so far encountered are numerous and have included a developing sense of ownership of the heritage by the local community and better understanding of the archaeological evidence and its history in connection to the local population, especially regarding earthen architectural practices (Figure 2.3).

Although the project so far has met with positive feedback, the lack of diversity in gender participation is perceived as one of the few shortcomings. The project has involved only a limited number of female adults (i.e. one woman as compared to eight man). However, one of 
the future aims is to extend the targeted audience to include a more gender-balanced population, with specific earthen architectural workshops targeted to women, where they can feel more empowered to share their knowledge and expertise regarding their role in the building process. This difficulty demonstrates the need for long term bridge building and trust building within the community, which could not be achieved in the short timeframe of one excavation season.

\section{Future Perspectives}

The project from Timai together with the other case studies described above demonstrate the ways in which community engaged-research relies on a more equitable sharing of knowledge regarding the reconstruction of the past, for instance documenting how the architectural process is often a community activity that includes both men and women in the process (Boivin 2008; Joshi 2011; Prussin 1974; Dalton 2017; Blier 1981; van Vuuren 2008a; Odiaua 2008). This provides archaeologists focusing on earthen architecture in Africa with new insights and new approaches to overcome the previous limitations regarding of the inclusions of gender narratives in the creation of historical architecture. Through the inclusion of local communities who possess unique knowledge and expertise as active agents of the construction process, archaeologists can develop a more holistic interpretation that utilizes a multi-vocal narrative and framework for interpreting the past.

The built environment plays a critical role in the life of past and present communities as the artificial, human-made landscape, in which interactions take place, peoples' beliefs and values are tangibly represented, and as a space for industriousness and creativity. The case studies discussed in this chapter highlight two important points of theoretical progress in the 
development of a more inclusive discipline. First are the different ways in which postcolonial theories have impacted the analysis of architecture, especially the inclusion of gender and ethnoarchaeological studies, by exposing the existence of a persistent bias in building archaeology that rarely acknowledges the role of the female workforce in the architectural process. This preconceived notion plays a significant role in the archaeologists' understanding of the archaeological record and it is at the origin of subsequent misconception in the analysis of the built environment. Second, building archaeology as a discipline can assist in overcoming fixed Western perspectives not only by incorporating postcolonial theories, but also by including multiple viewpoints from academics and indigenous communities, integrating local histories, and largely decolonizing the discipline. By reevaluating the archaeological data through these lenses, we can better understand the role of diverse individuals in architecture, especially women (Blier 1981; Dalton 2017; Elcheikh 2018). Such an undertaking is particularly relevant at the current socio-cultural moment, as there is an urgent need for a more gender-inclusive narrative in creating and managing archaeological projects that can positively impact local communities (Elcheikh 2018; Humphris and Bradshaw 2017).

The African case studies presented here are a representative example of reevaluating archaeological and ethnographical data to provide a more holistic interpretation of the built environment. The primary goal is to bring agency back to the overlooked part of the communities, who often play an active role in the architectural process. Not only that, communities - together with archaeologists — are the stewards of intangible and tangible heritage, and they are entitled to have an active voice in its preservation and representation. Architectural remains have an important role in the archaeological contexts, but they are also an active subject of interest for local communities' agency, therefore there must be a participatory 
component in any archaeological study to bridge different perspectives (Moser et al. 2002; Lorenzon and Zermani 2016; Schmidt and Pikirayi 2016; Kusimba 2017). Finally, building archaeology should aim at displaying two main functions, academic and civic, this latter voicing communities' perspectives as participant stakeholders.

\section{Figures}

Figure 2.1. Plaster layered by the women in the Amara community (Photograph by Matthew Dalton, Amara West Research Project. Courtesy of the Trustees of the British Museum).

Figure 2.2. Wall painting with Zaalenga and Wanzagesi, Sirigu, Ghana, March 9, 2013. (Photo courtesy of Brittany Sheldon).

Figure 2.3. Mudbrick manufacturing in Egypt, Tell Timai (Photo: M. Lorenzon)

\section{References}

Arceneaux, K. D. (1989). The script-analogue and its application in architectural analysis: the relationship of African women to African traditional architecture. Doctoral thesis submitted to Virginia Polytechnic Institute and State University.

Archer, J. (2005). Social theory of space: Architecture and the production of self, culture, and society. Journal of the Society of Architectural Historians, 64(4), 430-433.

Atalay, S. (2012). Community-based archaeology: Research with, by, and for indigenous and local communities. Univ of California Press.

Aurenche, O. (1993). L'origine de la brique dans le Proche-Orient ancien. In M. Frangipane M. \& A. Palmieri (Eds.), Between the rivers and over the mountains: Archaeologica 
Anatolica et Mesopotamica Alba Palmieri Dedicata, (pp. 71-85). Rome: Università di Roma La Sapienza.

Bartlett, A. E. A. (1994). Spatial order and psychiatric disorder. In M.P. Pearson \& C. Richards (Eds.), Architecture and order (pp. 178-195). New York: Routledge.

Butzer, K. (1976). Early hydraulic civilization in Egypt. Chicago University Press: Chicago.

Blier, S. P. (1981). Architecture of the Tamberma (Togo). Doctoral thesis submitted to Columbia University.

Blier, S. P. (1994). The anatomy of architecture: ontology and metaphor in Batammaliba architectural expression. Chicago, IL: University of Chicago Press.

Blier, S. P. (2006). Vernacular architecture. In C. Tilley, W. Keane, S. Kuechler, M. Rowlands, \& P. Spyer (Eds.) Handbook of material culture (pp. 230-253). New York: SAGE Publications.

Boivin, N. (2008). Material cultures, material minds: the impact of things on human thought, society, and evolution. Cambridge: Cambridge University Press.

Brunskill, R. W. (2000). Vernacular architecture: An illustrated handbook. London: Faber and Faber (4th edition).

Bourgeois, J. L. (1987). The history of the great mosques of Djenné. African Arts 20(3), 54-62.

Conkey, M., \& Spector, J. (1984). Archaeology and the study of gender. Advances in Archaeological Method and Theory, 7, 1-38.

Dalton M. (2017). Reconstructing lived experience of domestic space at Amarna West. In N. Spencer, A. Stevens, and M. Binder (Eds.), Nubia in the New Kingdom: Lived experience, Pharaonic control and indigenous traditions (pp. 357-388). Leuven: Peeters. 
Devolde, M. \& Lorenzon, M. (2019) "Minoan Master Builders? A Diachronic Study of Mudbrick Architecture in the Bronze Age Palace at Malia (Crete)." Bulletin de correspondance hellénique 143/1: 63-123.

Egenter, N. (1992). Architectural anthropology: The present relevance of the primitive in architecture. Structura Mundi I. Lausanne: Presses Centrales.

Elcheikh, Z. (2018). Tales from two villages: Nubian women and cultural tourism in Gharb Soheil and Ballana. Dotawo: A Journal of Nubian Studies, 5(1), 241-260.

Fodde, E. (2009). Traditional earthen building techniques in Central Asia. International Journal of Architectural Heritage, 3(2), 145-168.

Gamble, C. S. \& Porr, M. (Eds.). (2005). The hominid individual in context: archaeological investigations of Lower and Middle Palaeolithic landscapes, locales and artefacts. London: Routledge.

Gilchrist, R. (1997). Ambivalent bodies: gender and medieval archaeology. In J. Moore and E. Scott (Eds.), Invisible people and processes: Writing gender and childhood into European archaeology (pp. 88-112). London: Leicester University Press.

Gilchrist, R. (1999). Gender and archaeology: Contesting the past. London: Routledge. Gilchrist, R. (2004). Archaeology and the life course: a time and age for gender. A companion to social archaeology, 142-160.

Glassie, H. (1984). Vernacular architecture and society. Material Culture, 16(1), 4-24.

Glassie, H. (2000). Vernacular architecture. Bloomington: Indiana University Press.

Gosden, C. (2001). Postcolonial archaeology: issues of culture, identity, and knowledge. In I. Hodder (Ed.), Archaeological theory today (pp. 241-261). London: Blackwell. 
Güvenç, B. (1990). Vernacular architecture as a paradigm-case argument. In M. Turan (Ed.) Vernacular architecture: Paradigms of environmental responses (pp. 284-288). Aldershot: Averbury.

Hanna, M. (2013). What has happened to Egyptian heritage after the 2011 unfinished revolution? Journal of Eastern Mediterranean Archaeology \& Heritage Studies, 1(4), 371-375.

Herrmann, G. (1999). Monuments of Merv: Traditional buildings of the Karakum. London: Society of Antiquaries of London.

Hodder, I. (1994). Architecture and meaning: The example of Neolithic houses and tombs. In M. P. Pearson and C. Richards (Eds.), Architecture and order (pp. 73-86). New York: Routledge.

Hodder, I. (Ed.). (2000). Towards reflexive method in archaeology: the example at Çatalhöyük (No. 28). Cambridge, U.K.: McDonald Institute for Archaeological Research, University of Cambridge.

Holter, U. (1995). Mahria tents: the woman's domain. In L. Prussin, African nomadic architecture: space, place and gender (pp. 124-149). Washington: Smithsonian Institution Press and the National Museum of African Arts.

Horton, M. (1994). Swahili architecture, space and social structure. In M. P. Pearson and C. Richards (Eds.), Architecture and order (pp. 147-169). New York: Routledge.

Humphris, J., and Bradshaw R. (2017). Understanding "the community" before community archaeology: A case study from Sudan. Journal of Community Archaeology \& Heritage, 4(3), 203-217.

Ikram, S. (2013). Cultural Heritage in Times of Crisis: The View from Egypt. Journal of Eastern Mediterranean Archaeology \& Heritage Studies, 1(4), 366-371. 
Ingold, T. (2000). The perception of the environment: essays in livelihood, dwelling and skill. London: Routledge.

Jolaoso, A.B. (2001). Housing and indigenous building technology. Abeokuta, Nigeria: DesiOga Publication.

Joshi, O. P. (2011). Earthen Architecture in Indian Tribes. In L. Rainer, A. B. Rivera and D. Gandreau (Eds.), TERRA 2008: the 10 International conference on the Study of Conservation of Earthen Architectural Heritage, (pp.109-113), Los Angeles, California: Getty Publications.

Joyce, R. A. (2000). A precolumbian gaze: Male sexuality among the Ancient Maya. In R. Schmidt and B. Voss (Eds.), Archaeologies of Sexuality (pp. 263-283). London: Routledge.

Joyce, R. A. (2004). Embodied subjectivity: Gender, femininity, masculinity, sexuality. In L. Meskell and R. W. Preucel (Eds.), A companion to social archaeology (pp. 82-95). Oxford: Blackwell.

Kusimba, C. M. (2017). Community archaeology and heritage in coastal and Western Kenya. Journal of Community Archaeology \& Heritage, 4(3), 218-228.

Leakey, L. S. B. (1977). The southern Kikuyu before 1903 (Vol. 2). New York: Academic Press.

LeMoine, G. (2003). Woman of the house: Gender, architecture, and ideology in Dorset prehistory. Arctic Anthropology, 40(1), 121-138.

Liebmann, M. 2008. Introduction: The intersections of archaeology and postcolonial studies. In M. Liebmann and U. Z. Rizvi (Eds.), Archaeology and the postcolonial critique (pp. 1-21). Plymouth (U.K.): AltaMira.

Lorenzon, M. and Sadozaï, C. (2018). From past to present: Building skill transfer in Tajikistan. 
In T. J. Joffroy, H. Guillaud, \& C. Sadozaï (Eds.), Terra Lyon 2016. Proceedings of the $12 t^{h}$ World Congress on Earthen Architecture. Articles sélectionnés pour publication en ligne / articles selected for on-line publication / artículos seleccionados para publicación en línea. Villefontaine: CRATerre. Available at https://craterre.hypotheses.org/files/2018/05/TERRA-2016_Th-1_Art-226_Lorenzon.pdf. Accessed 10 June 2019

Lorenzon, M. \& Zermani, I. (2016). Common ground: Community archaeology in Egypt, Interaction between population and cultural heritage. Journal of Community Archaeology \& Heritage, 3(3), 183-199.

McKinnon, J., Mushynsky, J., \& Cabrera, G. (2014). A fluid sea in the Mariana Islands: Community archaeology and mapping the seascape of Saipan. Journal of Maritime Archaeology, 9(1), 59-79.

Miller, V. (Ed.). (1988). The role of gender in pre-Columbian art and architecture. Lanham, Maryland: University Press of America.

Mills, S. (2013). Gender and colonial space. Manchester: Manchester University Press.

Morris, J. \& Blier, S. P. (2004). Butabu: Adobe Architecture of West Africa. New York: Princeton Architectural Press.

Morton, C. (2007). Remembering the house: Memory and materiality in Northern Botswana. Journal of Material Culture, 12(2), 157-179.

Moser, S., Glazier, D. Phillips, J. E., Nasser el Nemr, L., Mousa, M. S., Nasr Aiesh, R., Richardson, S., Conner, A., and Seymour, M. (2002). Transforming archaeology through practice: Strategies for collaborative archaeology and the community archaeology project at Quseir, Egypt. World Archaeology, 34(2), 229-248. 
Nicholas, G. P., Welch, J. R. \& Yellowhorn, E. C. (2008). Collaborative encounters. In C. Colwell-Chanthaphonh \& T. J. Ferguson (Eds.), Collaboration in archaeological practice: Engaging descendant communities (pp. 273-298). Walnut Creek: Altamira Press.

Nicholas, G. P. (2010). Seeking the end of indigenous archaeology. In C. Phillips and H. Allen (Eds.), Bridging the divide: Indigenous communities and archaeology into the 21st Century (pp. 233-252). Walnut Creek: Left Coast Press.

Odeyale, T.O., \& Adekunle, T.O. (2008). Innovative and sustainable local material in traditional African architecture - Socio cultural dimension. In D. D’Ayala \& E. Fodde (Eds.), Structural analysis of historic construction: Preserving safety and significance. Proceedings of the 6th international conference on structural analysis of historic construction, SAHC08, (pp. 991-998). London: CRC Press.

Odiaua, I. (2008). Earth building culture in Daura, Nigeria: From mythological origin to reality. In L. Rainer, A. B. Rivera, \& D. Gandreau (Eds.), TERRA 2008: The $10^{\text {th }}$ international conference on the study of conservation of earthen architectural heritage (pp. 120-123), Los Angeles, CA: Getty Publications.

Prussin, L. (1969). Architecture in northern Ghana: A study of forms and functions. Berkeley: University of California Press.

Prussin, L. (1974). An introduction to indigenous African architecture. Journal of the Society of Architectural Historians, 33(3), 183-205.

Prussin, L. (1995). African nomadic architecture: Space, place and gender. Washington, DC: Smithsonian Institution Press.

Rapoport, A. (1969). House form and culture. Englewood Cliffs, NJ: Prentice-Hall. 
Rapoport, A. (1976). The mutual interaction of people and their built environment: A crosscultural perspective. The Hague: Mouton Publishers.

Schmidt, P. R. (1983). An alternative to a strictly materialist perspective: A review of historical archaeology, ethnoarchaeology, and symbolic approaches in African archaeology. American Antiquity, 48(1), 62-81.

Schmidt, P. R. (2014). Rediscovering community archaeology in Africa and reframing its practice. Journal of Community Archaeology \& Heritage, 1(1), 37-55.

Schmidt, P. R., \& Pikirayi, I. (2016). Community archaeology and heritage in Africa: Decolonizing practice. London: Routledge.

Sheldon, B. (2017). Indigenous expertise: African women's artistry connecting across time and space. Africa Review, 9 (1), 13-27.

Sogah, F. T. (2010). The influence of traditional African art on African architecture. Master's thesis submitted to Kwame Nkrumah University of Science and Technology, Kumasi, Ghana. Available at: http://ir.knust.edu.gh/bitstream/123456789/317/1/fulltxt.pdf. Accessed 12 Apr 2019.

Sørensen, M. L. S. (1996). Women as/and metalworkers. In A. Devonshire \& B. Wood (Eds.), Women in industry and technology: From prehistory to the present. Current research and the museum experience (pp. 45-52). London: Museum of London.

Spector, J. D. (1983). Male/female task differentiation among the Hidatsa: Toward the development of an archaeological approach to the study of gender. In P. Albers and B. Medicine (Eds.), The hidden half: Studies of Plains Indian women (pp. 77-99). Lanham, Maryland: University Press of America. 
Steadman, S.R. (1996). Recent research in the archaeology of architecture: Beyond the foundations. Journal of Archaeological Research, 4(1), 51-93.

Strommenger, E. (1980). The chronological division of the archaic levels of Uruk-Eanna VI to III/II: past and present. American Journal of Archaeology, 84(4), 479-487.

Trigger, B.G. (1984). Alternative archaeologies: nationalist, colonialist, imperialist. Man, 19, $355-370$.

Tringham, R. (1994). Engendered places in prehistory. Gender, Place and Culture: A Journal of Feminist Geography, 1(2), 169-203.

Tringham, R., \& Chang, C. (1991). Men and women in prehistoric architecture. Traditional Dwellings and Settlements Review, 3(1), 9-28.

Upton, D. (1983). The power of things: Recent studies in American vernacular architecture. American Quarterly, 35, 262-279.

Van Dommelen, P. (2011). Postcolonial archaeologies between discourse and practice. World Archaeology, 43(1), 1-6.

Van Vuuren, C. J. (2008a). Features in the intangible domain of Ndebele earthen architecture. In L. Rainer, A. B. Rivera and D. Gandreau (Eds.), TERRA 2008: the 10 $0^{\text {th }}$ international conference on the study of conservation of earthen architectural heritage (pp. 141-146), Los Angeles, CA: Getty Publications.

Van Vuuren, C.J. (2008b). The intricacy of intangible cultural heritage: Some perspectives on Ndebele earthen architecture. South African Journal of Art History, 23(2), 14-24.

Whelan, D. (2003). Decorated architecture as material culture: A preliminary look at the vernacular architecture of the Msinga area. Southern African Humanities, 15(1), 129-141. Wylie, A., (1991). Gender theory and the archaeological record: Why is there no archaeology of 
gender? In J. Gero and M. W. Conkey (Eds.), Engendering archaeology: Women and prehistory (pp. 31-54), Oxford: Blackwell. 